https://doi.org/10.46344/JBINO.2021.v010i01.33

\title{
ARTHROPODS COMMUNITY ASSOCIATED WITH PHYSIC NUT (JATROPHA CURCAS L.) IN DRY LANDS (A CASE STUDY IN SUDAN)
}

ISHTIAG ABDALLA - MAHA ABD AL ATIF - AWATIF KHIDIR OMER

Desertification Research Institute, National Research Center, Khartoum - Sudan ELSHEIKH ABDALLAH ELBADRI UNIVERSITY, BERBER-SUDAN

\section{ABSTRACT}

Jatropha curcas L. is a multipurpose shrub of significant economic importance for its potential economic and medicinal uses. As a shrub; Jatropha $\mathrm{sp}$ is an indigenous plant inhabited many parts in Sudan states such as central, eastern and western states. As a promising plant, Jatropha curcas L. has been grown in El Rawakeeb Dry land Research Station for economic and environmental purposes. A field study was conducted at El Rawakeeb Dry land Research Station during October - December 2012 to evaluate arthropods diversity in association with Jatropha curcas L. The study included identification and quantification of arthropods using three extraction methods: (Hand sorting, Pit fall trap and butter fly net). The three methods revealed1169 individuals identified into 2 classes (Insecta and Arachnida) 12 orders, and 18 families. Statistical analysis of data showed that members of class Insecta dominated the obtained fauna. At order level members of orders Thysanura, Odonata, Isoptera, Orthoptera, Dictyoptera, Hemiptera, Neuroptera, Coleoptera, Diptera, Lepidoptera and Hymenoptera were most dominant whereas, one order of class Arachnida (i.e. Araneae) was obtained. These results could be ascribed to the ability of insects to withstand different environmental conditions. Within the class Insecta; order Hymenoptera dominated the other orders followed by Isoptera, Coleoptera and Diptera. Simpson's diversity index obtained showed high arthropods diversity (0.6). The higher index of diversity is due to the positive impact of Jatropha curcas L. cultivation in this dry area which works on returned back of some disappeared species due to the drought which hit the area in the eighties of the lastcentury.

Keywords: Jatropha; arthropods; diversity; drought. 


\section{Introduction}

The development of bio-energy system has attracted considerable public, commercial and scientific attention as a potential solution for the global climate and energy crisis (Rajesh et al., 2008; King et al., 2010). Jatropha curcas L. is a biofuel crop, widely cultivated in Africa, Central and South America, India and Southeast Asia (Katembo and Gray 2007; Maes et al., 2009), mainly because of the high quality oil it produces and its ability to reclaim dry, marginal and degraded areas (Achten et al., 2008; Achten et al., $2010 \mathrm{a}$ and 2010b). It is a tropical, drought resistant, stem succulent tree originating from continental central America (Kaushik et al., 2007; Kumar and Sharma, 2008; Maes et al., 2009; Trabucco et al., (2010). Jatropha curcas L. . is monoecious and flowers during rainy seasons in racemose inflorescences, which follow a dichasial cyme pattern; wherein both male and female flowers develop (Carels, 2009; Achten et al., 2010b).

Jatropha has been known in many countries in Sub- Saharan Africa for generations. It has been planted as hedges (to serve as a "living fence") or has been used for artisan soap production or medicinal purposes. Today, significant investments in cultivating Jatropha as an energy crop take place in Africa. In Sudan, Jatropha curcas $L$ is found in many areas such as Khartoum State in east and Kordofan State in the west of the country (Renner, 2008).

Diversities of organisms (both pests and non pests) are associated with most of these plants, According to earlier works; they could either be defoliators, visitors, predators of other species or they are pollinators. The aim of this study is to identify arthropods associated with this plant. It also meant to clarify the distribution of arthropods in relation to the plant zone.

\section{Material and Methods Study area:}

The study was conducted in ElRawakeeb dry land which occupies the area southwestern Omdurman Governorate. It lies about $45 \mathrm{~km}$ away from the capital Khartoum between latitudes $15^{\circ} 2^{\prime}$ and 15\%36' North and longitudes $32^{\circ} 0^{\prime}$ and $32^{\circ} 10^{\prime}$ East.

The Micro morphological features in the region include the system of drainage, one drain to the White Nile and the other to the west of it. The general geological feature is the Nubian sand stones, which cover the Basement Complex. The sand tones consist mainly of consolidated sediments of conglomerates, sandstones and mudstones, which outcrop in low levels indicating the major processes that took place to erode these rocks. These stones are highly joined and sometimes cemented with silica and irons. ElRawakeeb soil following the direction of its water flow showed that the

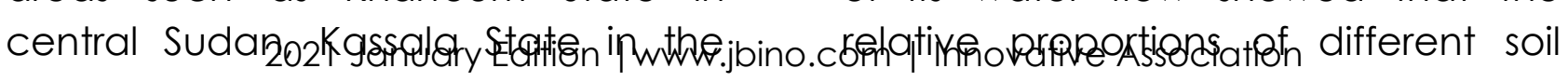


particles follow the order: sand, silt and clay where sand comprises the higher proportion. Chemically, ElRawakeeb soil is generally alkaline; very poor in Nitrogen and organic Carbon, moderate in its bicarbonate and Potassium contents and rich in its Sodium, Calcium and Chloride contents, El Hag et al (1994).

The climate of the area is characterized by a short rainy season (July- October) and high evaporation potential (Fig.1). The relative humidity values are low which indicate the general aridity of the area. Air temperature values fluctuate and show marked rise in May and drop in July and August due to the incidence of rains(Fig.2).

El-Rawakeeb area lies in semidesert scrub and Grassland on Basement complex soils and part of Acacia Desert Scrub" and can be included in the "A cacia tortilis Maerua crassifolia" subdivision of semi-desert.

The system of land use in ElRawakeeb is mainly pastoral. Traditional agriculture activities are usually carried out. Fodder crops, vegetables and shelterbelts are cultivated and irrigated artificially.

\section{Arthropods collection:}

Twelve Jatropha curcas L. trees were selected randomly to study arthropods fauna. Sampling was carried out weekly, starting from the October 2012 to December 2012 and from October 2013 to December 2013 using the following methods of collection and preservation described by Gibb and Oesto (2006). Collection methods are as follows:

\section{Hand collecting method:}

Arthropods fauna were sampled using forceps from leaves, flowers, and fruits stem (branches) and surface soil surrounding the trees. Specimens collected by the three methods were then kept in jars filled with $70 \%$ ethyl alcohol to kill the specimens and preserve them for further identification.

\section{Butter fly net method}

This method was used to collect aerial insects feeding or resting on the top of tree pats. 


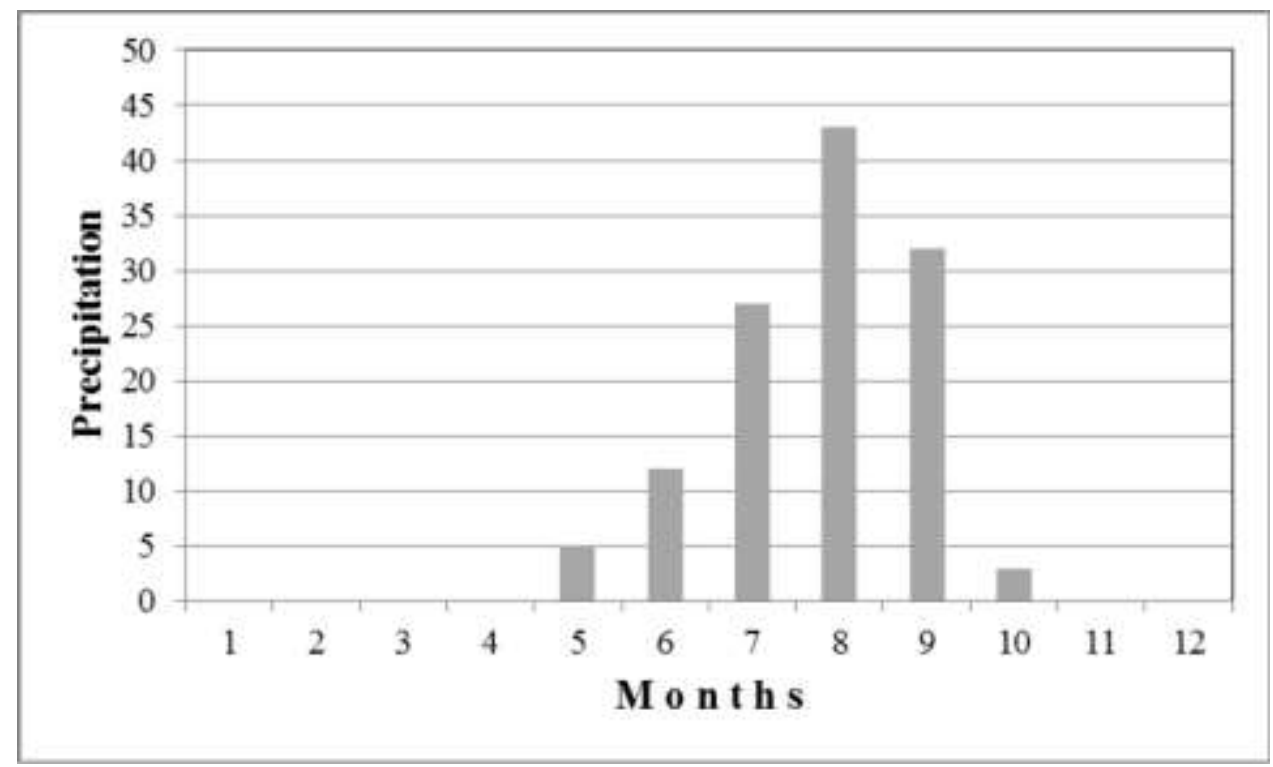

Fig. 1: Mean monthly rainfall in Khartoum State during the study period

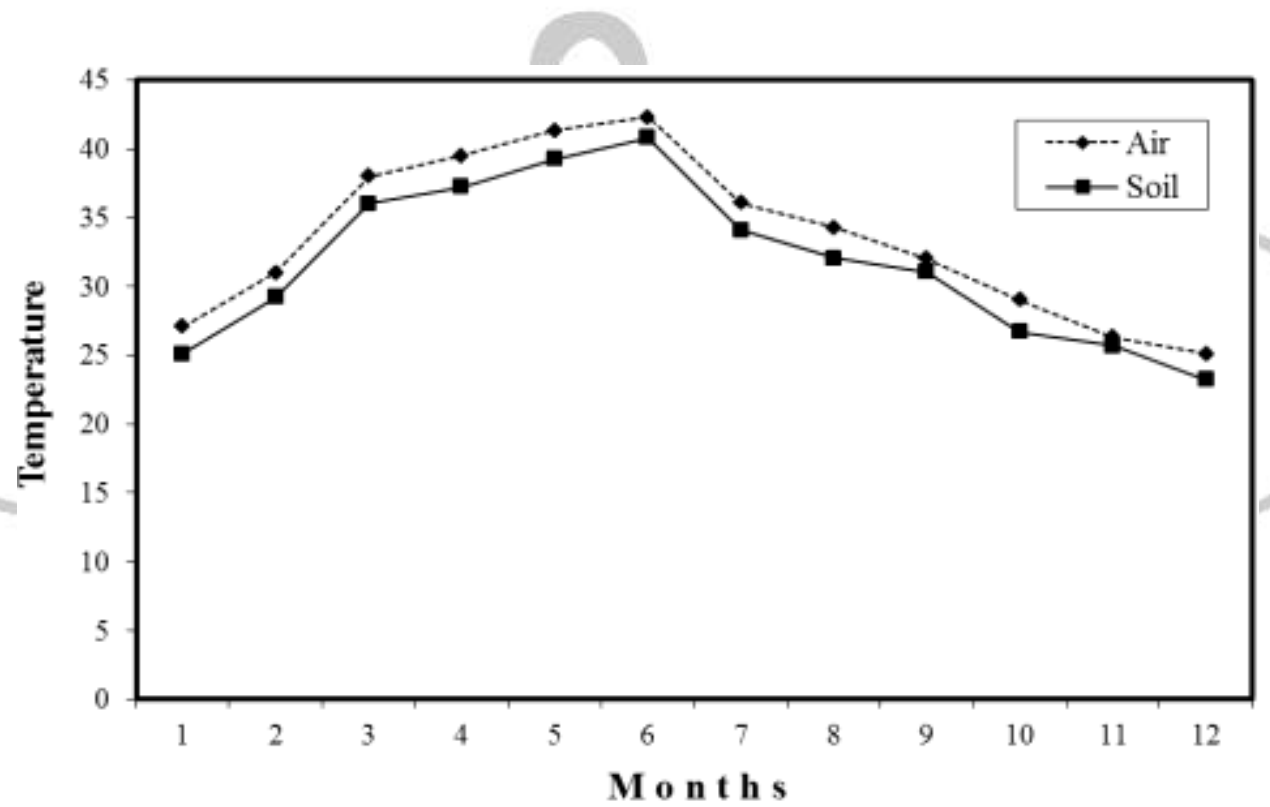

Mean monthly air and soil temperature as recorded at El-Rawakeeb dry soil during the study period

\section{Pitfall traps:}

Twelve jam jars were buried into the ground. Traps were arranged in straight line of twelve traps at one $\mathrm{m}$ intervals. The jars were kept for a week after which arthropods were collected and preserved in $70 \%$ ethanol for further identifications.

\section{Statistical analysis:}

Simpson's index (D) was used to calculate arthropods diversity. It is a measure of diversity, which takes into account both species richness, and an evenness of abundance among the species present. In essence it measures the probability that two individuals randomly selected from an area will belong to the same species, Simpson (1949). The formula for calculating D is presented as

$$
\mathrm{D}=\sum_{\mathrm{n}_{i}\left(\mathrm{n}_{i}-1\right)}
$$


Where: $\mathrm{N}(\mathrm{N}-1) \mathrm{ni}=$ the total number of organisms of each individual species $\mathrm{N}=$ the total number of organisms of all species

The value of $\mathrm{D}$ ranges from 0 to 1 . With this index, 0 represents infinite diversity and, 1 , no diversity. That is, the bigger the value the lower the diversity. The $\mathrm{D}$ value was subtracted form 1

i.e. 1- D value was obtained thus the greater the value the greater diversity would be obtained.

\section{Results and discussion Identification of arthropods:}

The collection of insects in the two study sites revealed 1169 faunal taxa identified into 11 orders, and 18families as shown in Table (1). Figure (3) illustrated that member of class Insecta dominated the total collection in terms of individual numbers and orders. This mode of dominance might be due to the ability of insects to proliferate under varied habitat conditions. Insects' morphology; including small boy size enables them to have permitted exploitation of habitat and food resources at a microscopic scale. Insects can take shelter from adverse conditions in microsites too small for larger organisms, Crawford(1979).

Moreover, having an exoskeleton provides protection against predation and desiccation

or water-logging and innumerable points of muscle attachment for flexibility. Also, insects' metamorphosis permits partitioning of habitats and resources among life stages. Immature and adult insects can differ dramatically in form and function and thereby live in different habitats and feed on different resources; reducing intraspecific competition, Schowalter, (2006). Insects might be able to overcome the natural insecticidal toxicity of Jatropha curcas. Similar observations were recorded by Banjo et al (2006).

\section{Abundance and diversity of Arthropods}

Figure (4) showed arthropods relative abundance, it illustrated that highest value was recorded by order Hymenoptera followed by Isoptera. Least relative abundances were attained by members of the orders Neuroptera and Dictyoptera. The high hymenoptera abundance could be ascribed to the effect of Jatropha curcas $L$. to attract these insects which may probably play a large role in the transport of pollen between flowers, inflorescences and trees. Similar observations were reported by Banjo et al. (2006) in Nigeria, Raju and Ezradanam (2002) in India and Rianti et al. (2010) inlndonesia.

\section{The diversity index}

The diversity index of Arthropods caught on Jatropha curcas L. was shown on table (2). It indicated that the diversity indices were: 0.36 for Orthoptera, 0.47 for Hemiptera, 0.46 for Coleoptera, 0.50 for Diptera and 0.98 for Hymenoptera. Thus; Hymenoptera showed the highest diversity index of the total arthropods. This could be due the availability of food resource for phyto-phagous individuals as well as for the predators' ones. Césard, (2004) detected that some 
Editors: Recep Efe, Ibrahim Atalay, Isa Cürebal

hymenopteran insects are generalist predator that feed on the honeydew exudate of mealy bugs as well as on the larvae of Diptera, Coleoptera. Also, Uddin et al (2012) claimed that some Hymenopteran insects associated with Jatropha curcas L. .are of economic importance such as the pollinator bees.

Orthoptera showed the lowest diversity index (table 2). This result could be assigned to the low density of Jatropha curcas L. plantation that might be below these defoliators satisfaction. Similar conclusions were attained by Banjo et al. (2006).

Table 1. Systematic list of insects collected from Jatropha curcas L. plantation

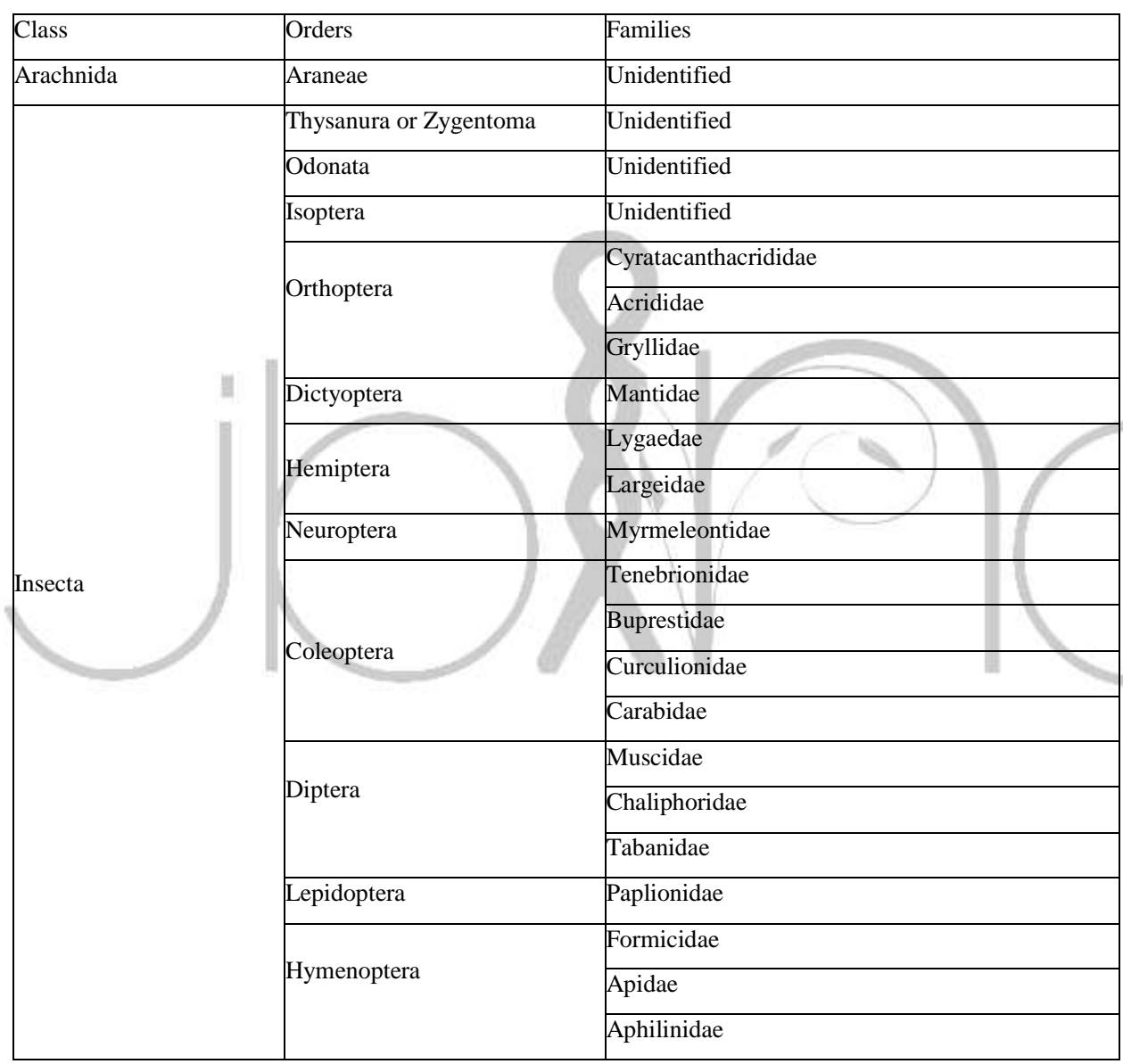

\section{Species richness}

The species richness for Arthropods caught on Jatropha curcas L. were given in table (2). It was found to be 1 for Arenae, Thysanura, Odonata, Dictyoptera and Neuroptera. The species richness was 2 for Hemiptera, 3 for Orthoptera and Diptera while it was found to be 4 for Coleoptera,table(2). Thevariationinspe ciesrichnessofarthropodscaughtonJat rophacurcas

L. could be due the variation in their feeding habit added to effect of the fluctuation in temperature values recorded throughout the study period 
where some arthropods may not be able to with stand thermal fluctuations. These results were agreed to the former findings of Chapman, (1972), who addressed that insects develop usually within a limited range of temperature outside which insects may suffer or die.
The highest species richness value shown by Coleoptera could be attributed to the feeding activity of some Coleoptera as plant pest. C Shanker and Dhyani, (2006), reported some coleopteran insects among Jatropha curcas L. pests.

Appendix (1): Shows some aspects of the study area and Jatropha curcas plantations:

Jatropha curcas $\mathrm{L}$

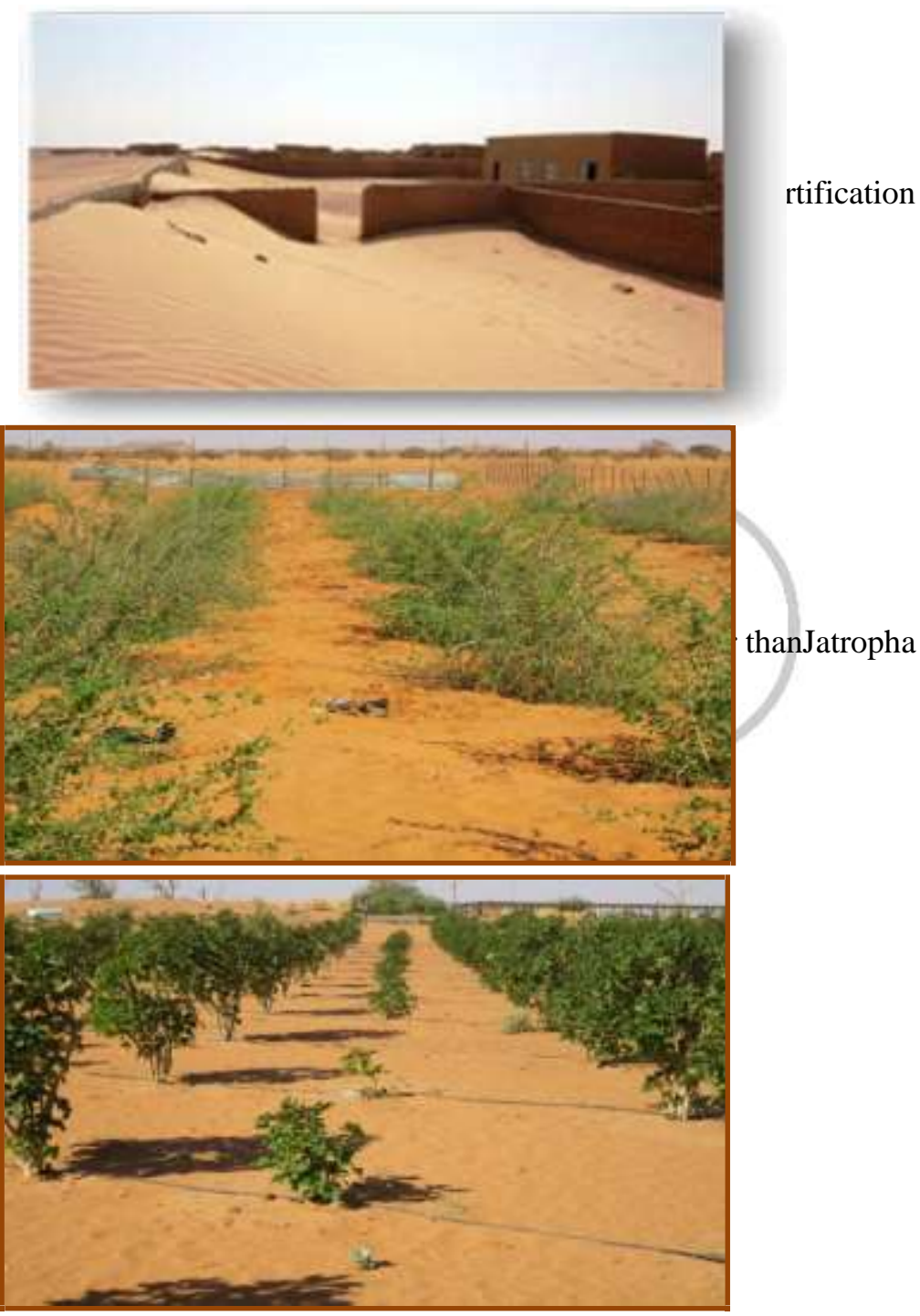


Jatropha curcas L. seedlings

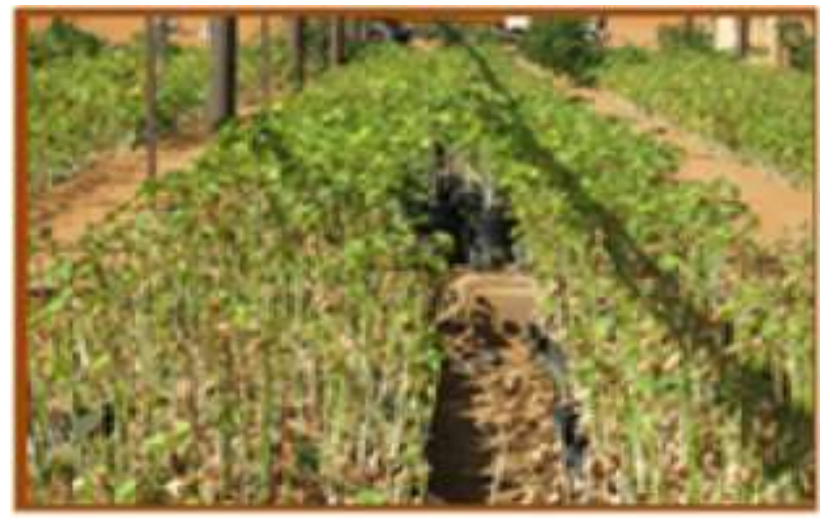

Table 2: Diversity of arthropods caught on Jatropha curcas $L$.

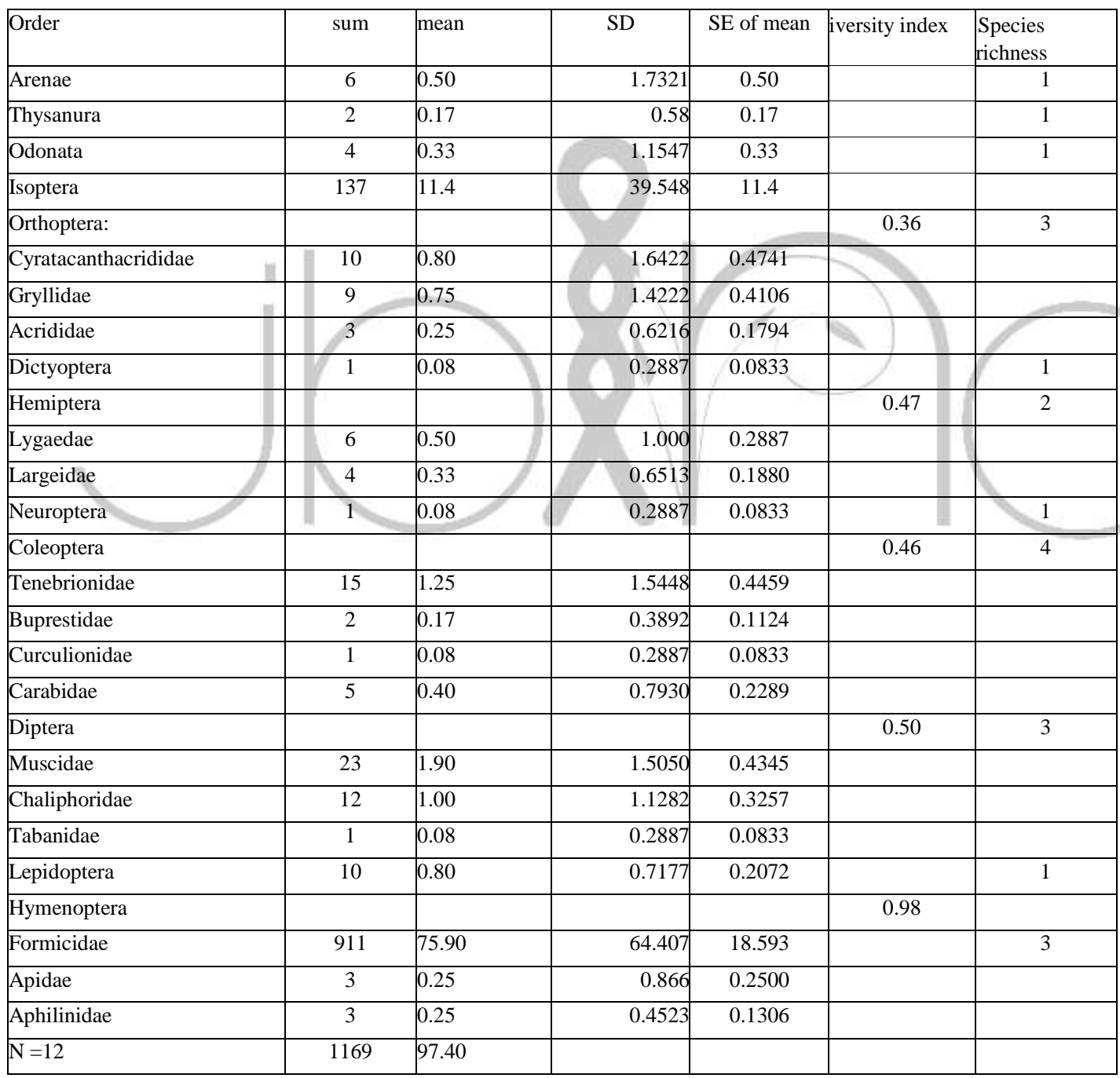




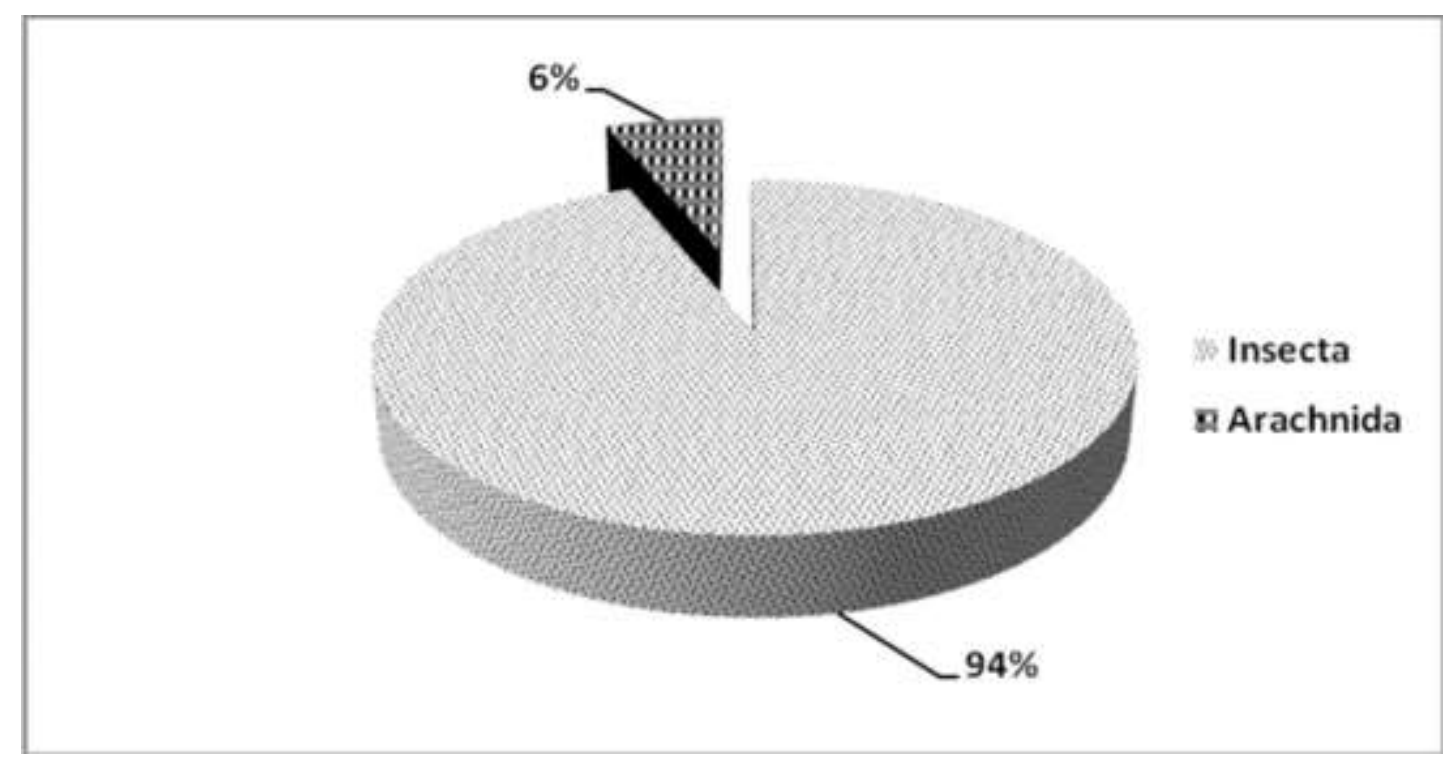

Fig. 3: Pie chart showing the dominance of arthropods collected from Jatropha curcas L. during the study period

Appendix (2): Shows some photos of arthropods associated with Jatropha curcas L collected during the study Order period:

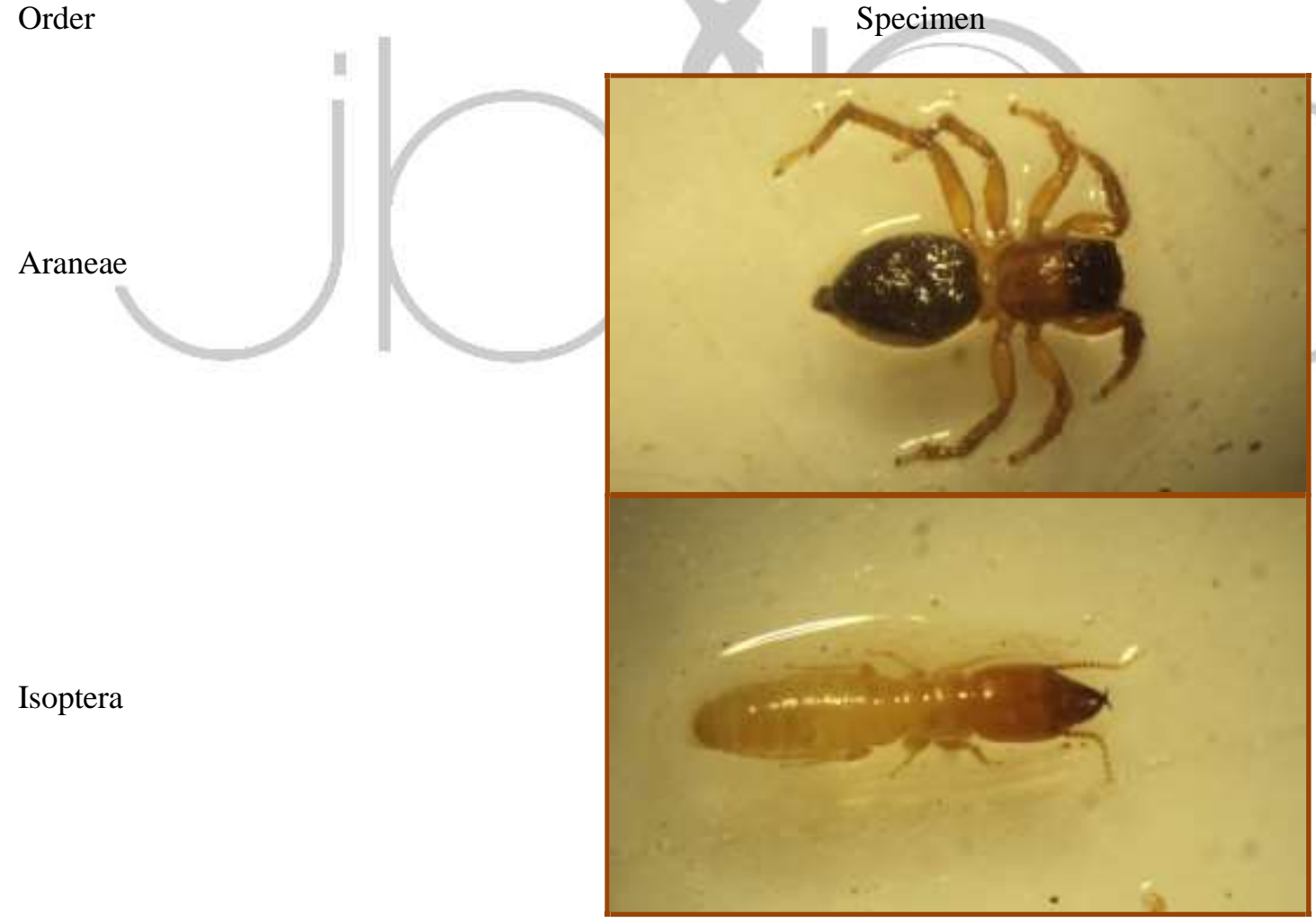

2021 January Edition | www.jbino.com | Innovative Association 
Orthoptera

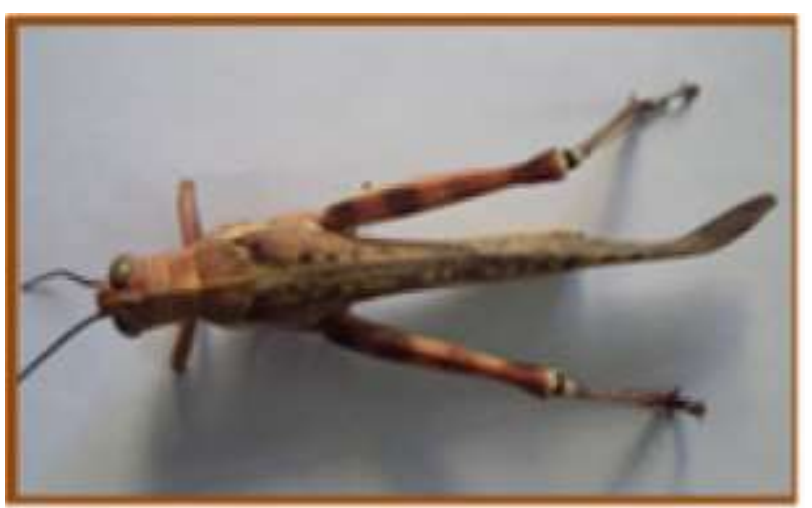

Dictyoptera

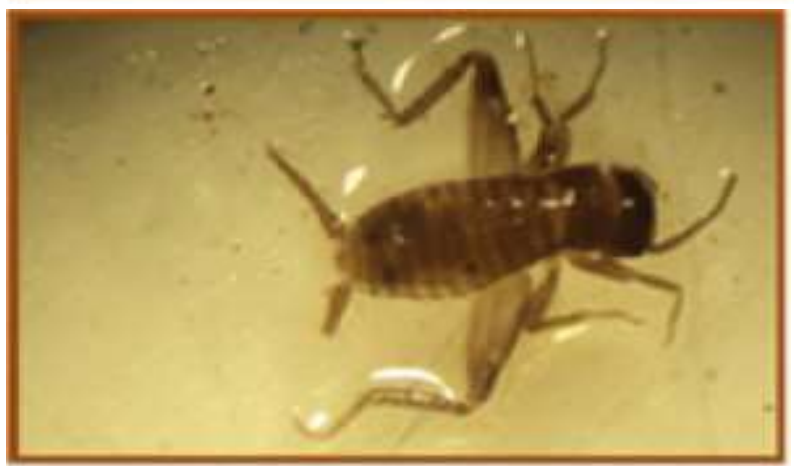

Hemiptera
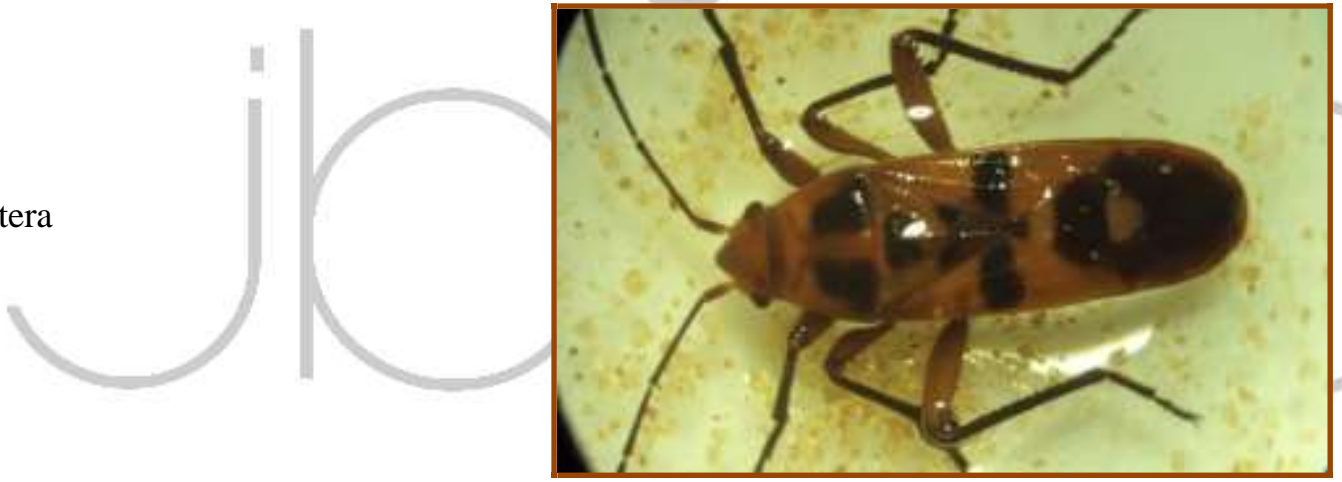

Coleoptera

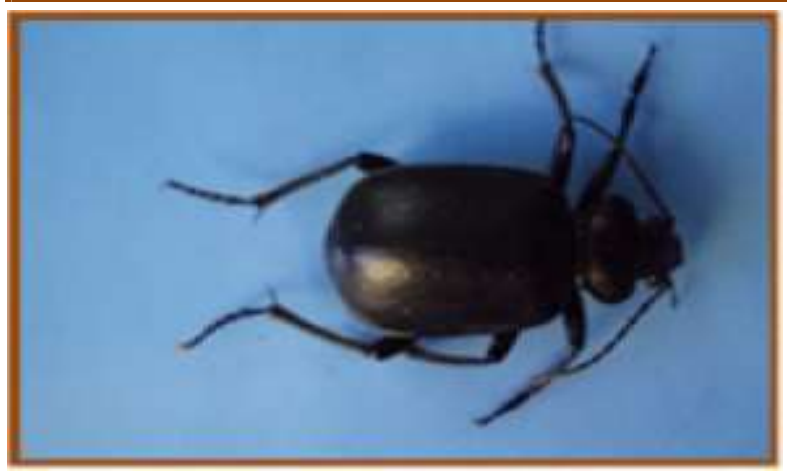

2021 January Edition | www.jbino.com | Innovative Association alne 


$$
=
$$




\section{Conclusion}

Arthropods community associated with the physic nut Jatropha curcas $L$. showed variability in diversity and species richness. These variations were ascribed to the advantages provided by Jatropha plantations to the arthropods. Further research was recommended to clarify the ecological interrelationships between Jatropha and otherorganisms.

\section{References}

Achten, W. Verchot, L., Franken, Y., Mathijs, E., Singh, V., Aerts, R. and Muys, B. Jatropha

bio-diesel production and use. Biomass and Bioenergy 32:1063 1084, 2008.

Achten, W., Almeida, J., Fobelets, V., Bolle, E., Mathijs, E., Singh, V. , Tewari, D., Verchot, L. and Muys, B. Life cycle assessment of Jatropha biodiesel transportation fuel in rural India. Applied Energy 87:3652-3660, 2010a. Achten, W., Nielsen, L., Aerts, R., Lengkeek, A., Kjaer, E., Trabucco, A., Hansen, J. Maes, W., Graudal, L., Akinnifesi, F. and Muys, B. Towards domestication of Jatropha curcas $L$. Biofuel 1:91 - 107,2010b.

Banjo, A., Lawal, O. and Aina, S. The entomo -fauna of two medicinal Euphorbiacae in Southwestern Nigeria. Journal of Applied Sciences Research 2:858 - 863, 2006.

Bhagat R.B and Kulkarni, D.K. Evaluation of larvicidal and anti feedant potential of three Jatropha species against Spodoptera litura (Lepidoptera: Noctuidae) and two predators, 2012.

Carels, N. Jatropha curcas L.: A Review. Advances in Botanical Research 50:39-85, 2009. Césard, N. Harvesting and commercialization of kroto (Oecophylla smaragdina) in the Malingping area, West Java, Indonesia. In: Kusters, K. \& Belcher, B. (Eds.): Forest products, livelihoods and conservation. Case studies of nontimber forest product systems. Center for International Forestry Research, Jakarta, pp. 61-78, 2004.

Chapman, R.F. Insects' structure and functions: The English Language Book Society and Hodder and Stoughton publishers. Pp.818, 1972.

Crawford, C.S. Desert detrivores: Review of life history patterns and trophic roles. Journal of Arid Environment 3, 142, 1979.

El Hag, M. EL-Hiraika; A.; EL-Hadi. S. and Saad S. Characterization of ELRawakeeb soil. Annual Scientific Report. Published by Environment and Natural Resources Research Institute, Khartoum, Sudan, 1994.

Gibb, T.J and Oesto, C.Y.Arthropod collection and identification: field and laboratory techniques.31 1p. Published by the academic press, USA, 2006.

Katembo, B.I. and Gray, P.S. Africa, seed and biofuel. Journal of MultiDisciplinary Research

1:1 - 6, 2007.

Kaushik, N., Kumar, K., Kumar, S. and Roy, S.Genetic variability and divergence studies in seed traits and oil content of Jatropha curcas $L$. accessions. Biomass and Bioenergy 
31:497 - 502, 2007.

King, A., Wei H., S.Cuevas, J. and Freudenberger, $M$. Potential of Jatropha curcas $L$. as a source of renewable oil and animal feed. Journal of experimental botany 60 : 2897 - 2905, 2010.

Kumar, A. and Sharma, S. An evaluation of multipurpose oil seed crop for industrial uses

Jatropha curcas L.: A review. Industrial Crops and Products 28:1 10, 2008.

Maes, W., Trabucco, A, Achten, W. and Muys, B. Climatic growing conditions of Jatropha curcas L. Biomass and Bioenergy 33:1481 - 1485,2009.

Orshoven, J., Norgrove, L. and Muys, B. Global mapping of Jatropha curcas $L$. yield based on response of fitness to present and future climate. Global Change Biology Bioenergy 2:139 151, 2010.

Rajesh, S., Raghavan, V., Shet, U. and Sundararajan, T. Analysis of quasisteady combustion of Jatropha bio-diesel Intl. Communications in Heat and Mass Transfer 35:1079 1083, 2008.

Raju, A. and Ezradanam, V.Pollination ecology and fruiting behavior in a monoecious species, Jatropha curca L (Euphorbiaceae). Current Science 83:1395 1398, 2002.

Renner A. Jatropha curcas $L$. is found in many areas such as Khartoum State in central Sudan, Kassala State in the east and Kordofan State in the west of the country. Published by the Global Exchange for Social Investment (GEXSI), Germany, 2008.

Rianti, P., Suryobroto, B. and Atmowidi, T.R.I. Diversity and Effectiveness of Insect Pollinators of Jatropha curcas L. (Euphorbiaceae). Journal of Biosciences 17:38 - 42, 2010.

Schowalter, T.D. Insect Ecology: An Ecosystem Approach (2nd Edition). Elsevier, Amsterdam, 2006.

Shanker, C. and Dhyani, K. Insect pests of Jatropha curcas $L$. and the potential for their management. Current science journal, 91 (2): 162 163, 2006.

Simpson, E H. Measurement of diversity. Nature, 163: 688, 1949. Trabucco, A., Achten W.M.J., Bowe, C., Aerts, R., Van

Orshoven, J.,Norgrove, L.andMuys,B.GI obal mapping of Jatropha curcas yield based on response of fitness to present and future climate global change biology Bioenergy 2:139151,2010 .

Uddin II, R.O., Liadi.M.T. and Ojoba, E.M. Insects species associated with the physic nut Jatropha curcas L. (Euphorbiaceae) in Ilorin, Nigeria. International journal of phyto fuels and allied sciences, 1 (1): 43-47, 2012. 